\title{
The attitudes of students to family and children: comparison of data for 2013 and 2019
}

\author{
Nadezhda Sivrikova ${ }^{1, *}$,Elena Kharlanova $^{1}$, Nadezhda Sokolova ${ }^{1}$, Viktoria Vasilyeva ${ }^{2}$, Svetlana Roslyakova $^{1}$ and \\ Nadezhda Sidorenko ${ }^{3}$ \\ ${ }^{1}$ Department of Social Work, Pedagogy and Psychology, South Ural State Humanitarian Pedagogical University, 69, Lenin prospect, \\ 454080, Chelyabinsk, Russia \\ ${ }^{2}$ Department of national history and law, South Ural State Humanitarian Pedagogical University, 69, Lenin prospect, 454080, \\ Chelyabinsk, Russia \\ ${ }^{3}$ Faculty of inclusive and correctional education, South Ural State Humanitarian Pedagogical University, 69, Lenin prospect, 454080, \\ Chelyabinsk, Russia
}

\begin{abstract}
The research into students' family values and attitudes is presented in the article. The authors compare the results of the polls which were taking place in 2013 and 2019 in Chelyabinsk. The general selection for the research was 174 persons (17-23-year-olds). 91 students (in 2013) and 83 students (in 2019) participated in the questionnaire. The results of the research have confirmed the tendencies to a decrease in the importance of the family as values found earlier among young people in Russia. It has been established that marriage as students view it is becoming freer from obligations, but it assumes reproduction in the form of the birth of children. The attitudes to the creation of their own family with two children in the long-term remain among students. Modern students want to build the relationship with the spouse as equals and to share obligations for children's upbringing between the husband and the wife. They consider that the age of $20-30$ is an optimum one for marriage and becoming a parent. The results of the research allow predicting the whole complex of demographic problems whose reasons are the decrease in the importance of the family; the decrease in the orientation to the parental family as a role model; the acceptance and approval of civil marriages.
\end{abstract}

\section{Introduction}

The demographic problem is one of the most burning issues in modern society. While in the countries of the West the population is reducing and the state is developing measures for the stimulation of a birth rate [1], significant efforts to decrease the birth rate in the East are made [2]. Researchers are discussing the issues connected with the aging population and the delayed childbearing [3]. Among the most burning issues are: disproportions in the formation of human, intellectual resources; an aggravation of social and economic problems; difficulties in the realization of the strategy of the innovative break.

A decline in the population was noted In Russia in 2018 for the first time since 2009. Researchers predict a deterioration in the age structure of the population. It is supposed that the share of women at the age of 20-29 which is the active reproductive period will decrease to $5.4 \%$ by 2020 (from $7.3 \%$ in 2015), and in 2025 it will make only $5 \%$ of the population of Russia [4]. The growth of divorces among youth causes a concern [5].

Statistical data show that the measures to support young families taken by the state and the birth of children, the promotion of family values and a healthy lifestyle are not enough. Researchers come to a conclusion that it is necessary to conduct a serious scientific research on the factors of a birth rate for the purpose of rendering a real help to young couples [6].

The structural changes in the family $[3,7,8]$, premarital cohabitation and marriage $[9,10,11]$, the change in gender family roles $[12,13]$, the influence of the social policy on a birth rate [1] draw attention of researchers. A special attention is paid to family values of youth $[5,6.7,14,15,16]$ which are considered as a key source of a psychosocial adaptation [15].

The monitoring of family values and attitudes of youth which has been carried out for the last decades demonstrates the relevance of this subject for the society. It allows to define transformation trends in this sphere.

The results of the comparison of the statistical sources for the last decades have shown that the greatest changes have happened in the marital status of students [6]. New trends in the ideas of the matrimonial relations among youth in the different countries have been established: the acceptance of trial and civil marriages, the increase of an estimated age to become a parent and the decrease in the number of alleged children, the strengthening of aims at a joint life without children $[3,6,11]$. The contradiction between a high importance of the family in

\footnotetext{
Corresponding author: bobronv@,cspu.ru
} 
the hierarchy of values of youth and a large number of divorces in this age group is noted [5].

\section{Design/methodology/approach}

The research purpose consisted in studying the changes in the family values and attitudes among students of universities of Chelyabinsk which happened from 2013 to 2019.

The selection for the research was 174 persons (the students getting an education in such specialties as history, social work, psychology, economics, journalism, philology). 91 persons were interviewed in 2013;83 persons were interviewed in 2019. The age of respondents varies from 17 to 23 .

The questionnaire consisting of five blocks was used to collect the empirical data. The blocks included valuable orientations and life purposes of students; the students' idea of the family; the idea of their own future family; the factors influencing the formation of students' ideas of their own future family; the attitude to the birth and upbringing of children.

Pearson Chi-Square Tests were used for mathematical data processing.

\section{Results and Discussion}

Within the research, students' family values were analyzed. The results of the research have shown that the family remains one of the main values for students. It was put on the first place in the system of life values by $39.8 \%$ in 2019. But in 2013 the share of such students made $83.5 \%$. Distinctions are reliable at $p<0.001$ (table $1)$.

Table 1. Family rank in structure of values of students.

\begin{tabular}{|c|c|c|c|c|}
\hline \multirow{2}{*}{ rank } & \multicolumn{2}{|c|}{2013} & \multicolumn{2}{c|}{2019} \\
\cline { 2 - 5 } & $\begin{array}{c}\text { number } \\
\text { of } \\
\text { people }\end{array}$ & $\%$ & $\begin{array}{c}\text { number } \\
\text { of } \\
\text { people }\end{array}$ & $\%$ \\
\hline 1 & 76 & $83.5 \%$ & 33 & $39.8 \%$ \\
\hline 2 & 0 & $0 \%$ & 6 & $3 \%$ \\
\hline 3 & 0 & $0 \%$ & 3 & $3.6 \%$ \\
\hline 4 & 15 & $16.5 \%$ & 9 & $10.8 \%$ \\
\hline 5 & 0 & $0 \%$ & 33 & $39.8 \%$ \\
\hline \multicolumn{5}{|c|}{ Chi-Square Tests } \\
\hline $\begin{array}{c}\text { Pearson } \\
\text { Chi-Square }\end{array}$ & \multicolumn{5}{|c|}{59.2} \\
\hline Significant & \multicolumn{5}{|c|}{$\mathrm{p}<0.001$} \\
\hline
\end{tabular}

The results of many studies demonstrate that the family takes a high place in the structure of values of youth [5, $18,19,20]$. But during the repeated research conducted several years later, the family as the leading value was chosen by much fewer people [21]. And still according to the data obtained by A.A. Rean in 2017 the family as the most significant value was chosen by $72.5 \%$ from 5561 respondents at the age of 14-18 in Russia [5, 21].

Differences were recorded in the distribution of the participants of the research with the different attitude towards children as a family value (table 2 ).

Table 2. Child rank in structure of values of students.

\begin{tabular}{|c|c|c|c|c|}
\hline \multirow{2}{*}{ rank } & \multicolumn{2}{|c|}{2013} & \multicolumn{2}{c|}{2019} \\
\cline { 2 - 5 } & $\begin{array}{c}\text { number } \\
\text { of } \\
\text { people }\end{array}$ & $\%$ & $\begin{array}{c}\text { number } \\
\text { of } \\
\text { people }\end{array}$ & $\%$ \\
\hline 1 & 31 & $34 \%$ & 14 & $16.9 \%$ \\
\hline 2 & 26 & 28.6 & 16 & $19.3 \%$ \\
\hline 3 & 16 & $17.6 \%$ & 17 & $20.5 \%$ \\
\hline 4 & 1 & $1.1 \%$ & 15 & $18 \%$ \\
\hline 5 & 17 & $18.7 \%$ & 21 & $25.3 \%$ \\
\hline \multicolumn{5}{|c|}{ Chi-Square Tests } \\
\hline $\begin{array}{c}\text { Pearson } \\
\text { Chi-Square }\end{array}$ & \multicolumn{5}{|c|}{21.18} \\
\hline Significant & \multicolumn{5}{|c|}{$\mathrm{p}<0.001$} \\
\hline
\end{tabular}

$34 \%$ of the respondents placed children on the first place in the hierarchy of family values in 2013, the percentage was twice as little (16.9\%) in $2019.18 .7 \%$ of the students placed children on the last place in the hierarchy of family values in 2013 , and $25.3 \%$ of the students made the same in 2019. Distinctions are reliable at $\mathrm{p}<0.001$.

It is possible to draw a conclusion that the value of the family and children is gradually decreasing among young people, giving way to the career and education. At the same time students consider that everyone needs to start a family (63\%). 92\% of the respondents in 2013 and $82 \%$ in 2019 wanted to have a good family in the future. It should be noted that there is a divergence between students' values and their significant life purposes. Most likely, this results from the fact that they consider values from the position of the present, and they consider the purposes from the position of the future.

When planning their future family life, the students interviewed in 2013 and in 2019 would like to live separately from parents (100\% of the respondents). At the same time, they would like to build the relationship with the spouse as equals $(62 \%)$, or with the leading role of the man $(28 \%)$.

As an optimum age for marriage students called the age from 25 to $30(62.6 \%)$ in 2013 and $20-25(53 \%)$ in 2019. Distinctions are reliable at $\mathrm{p}<0.001$ (Table 3 ).

Table 3. Optimum age for marriage.

\begin{tabular}{|c|c|c|c|c|}
\hline \multirow{2}{*}{ age } & \multicolumn{2}{|c|}{2013} & \multicolumn{2}{c|}{2019} \\
\cline { 2 - 5 } & $\begin{array}{c}\text { number } \\
\text { of } \\
\text { people }\end{array}$ & $\%$ & $\begin{array}{c}\text { number } \\
\text { of } \\
\text { people }\end{array}$ & $\%$ \\
\hline $20-25$ & 26 & $28.6 \%$ & 44 & $53 \%$ \\
\hline $25-30$ & 57 & $62.6 \%$ & 32 & $38.6 \%$ \\
\hline
\end{tabular}




\begin{tabular}{|c|c|c|c|c|}
\hline $30-35$ & 0 & $0 \%$ & 5 & $7.2 \%$ \\
\hline $\begin{array}{c}\text { Does not } \\
\text { matter }\end{array}$ & 8 & $8.8 \%$ & 1 & $1.2 \%$ \\
\hline \multicolumn{5}{|c|}{ Chi-Square Tests } \\
\hline $\begin{array}{c}\text { Pearson } \\
\text { Chi-Square }\end{array}$ & \multicolumn{5}{|c|}{21.69} \\
\hline Significant & \multicolumn{5}{|c|}{$<0.001$} \\
\hline
\end{tabular}

The data obtained by us agree with the results of other researches. In particular, the trend of a delay of marriage among young students for several years was recorded among an overwhelming majority of the participants of the research conducted in Sverdlovsk Region [6]. According to the research conducted in the Netherlands in 2005-2006 teenagers at the age of 14-17 planned to marry at the age of about 25 [22].

It has been established in the research that $46 \%$ of the respondents expect that the period of courting will proceed more than half a year, and $52 \%$ consider that time doesn't matter in the matter. The students accept and approve a civil marriage (68\%). At the same time the participants of the research agree in the opinion that filing of marriage strengthens the marriage union (46\%).

Trends towards the distribution of civil marriages among young people correspond to the changes in the structure of marriage in western countries $[3,5,6,11$, 17, 21]. The studies have shown that in the modern world cohabitation without an official marriage is becoming a normal phenomenon. An increasing number of people live in civil marriages. Children are born in them. However, the quality of the relationship remains the highest in direct marriages [11]. According to Yu. R. Vishnevsky and M.V. Yachmeneva the fact that cohabitation has become a habitual phenomenon in Russia indicates significant valuable changes in public consciousness [6]. The researchers name the whole complex of problems created by a high extent of rooting of civil marriages. Of which the problem of "trial children" is most important.

The students interviewed in 2013 and 2019 were unanimous when determining the optimum age for the birth of the first child. About $45 \%$ consider that it is necessary to become a parent at 20-25 and the same number of the respondents consider the age of 25-30 as the most suitable for this purpose. It is interesting that similar trends are characteristic of youth of other countries too. For example, teenagers from the Netherlands in 2005-2006 called the age of 26-27 as an optimum one to become a parent [22].

The opinion of the students, the respondents at different times, didn't differ concerning the optimum number of children in the family. $71.4 \%$ in 2013 and $68.7 \%$ in 2019 considered that having 2 children in the family is the most acceptable option. $17.6 \%$ of the students in 2013 and $10.8 \%$ of the students in 2019 answered that an optimum number of children for the family is 3 . The obtained data agree with the results of the research of senior school students, carried out in Russia in 2017 [5, 21].

About $50 \%$ of the respondents consider children as a natural part of the family. At the same time about $45 \%$ of the respondents consider that the family without children has its pluses and minuses, $41 \%$ - are sure that a childless family is incomplete. $9.6 \%$ of the respondents interviewed in 2019 answered that they wouldn't like to have children.

The students interviewed in different years were unanimous answering the question of the factors which define the decision on the number of children in the family. Most often "the financial wellbeing" was called as a reason. The answer "psychological readiness for the child's birth" became the second most popular. The answer "physical health of future parents" appeared on the third place.

The fact that more than a half (63\%) of the participants of the research grew up in the families where two children were raised is important. $15 \%$ of the respondents had three children in the parental family.

The answers of the students to the question whether the parental family is an exemplar for the creation of their future family, differed in 2013 and in 2019 (table 4).

Table 4. Parental family as a sample for creation of own family.

\begin{tabular}{|c|c|c|c|c|}
\hline \multirow{2}{*}{$\begin{array}{l}\text { opinion of } \\
\text { students }\end{array}$} & \multicolumn{2}{|c|}{2013} & \multicolumn{2}{|c|}{2019} \\
\hline & $\begin{array}{c}\text { number } \\
\text { of } \\
\text { people }\end{array}$ & $\%$ & $\begin{array}{c}\text { number } \\
\text { of } \\
\text { people }\end{array}$ & $\%$ \\
\hline $\begin{array}{l}\text { The parental } \\
\text { family is an } \\
\text { example for } \\
\text { imitation }\end{array}$ & 89 & $97.8 \%$ & 49 & $59 \%$ \\
\hline $\begin{array}{l}\text { The parental } \\
\text { family is not } \\
\text { an example } \\
\text { for imitation }\end{array}$ & 2 & $2.2 \%$ & 34 & $41 \%$ \\
\hline \multicolumn{5}{|c|}{ Chi-Square Tests } \\
\hline $\begin{array}{l}\text { Pearson Chi- } \\
\text { Square }\end{array}$ & \multicolumn{4}{|c|}{39.76} \\
\hline Significant & \multicolumn{4}{|c|}{$\mathrm{p}<0.001$} \\
\hline
\end{tabular}

$97.8 \%$ of the respondents in 2013 and $59 \%$ of the respondents in 2019 were guided by their parental family as a role model. The obtained data agree with the conclusions made by A.A. Rean who specifies that ideas of youth of the future family are based upon the exemplars whose main source is the parental family (53.2\%). The author showed that $42 \%$ from 5561 persons aged from 14 up to 18 wanted that their future family resembled the one in which they grew up. 34\% were categorically against it [21]. A.A. Rean considers such ratio as a reason of unreadiness of youth to marriage and high statistics of divorces among young people [5]. The lack of exemplars and reference points of family life in their own family makes the question of the formation of family values and readiness for family life of students relevant.

About $80 \%$ of the participants of the research consider that both spouses have to be engaged in the upbringing of children. About $20 \%$ consider that all family members, including grandmothers and grandfathers, have to share this duty. The opinions on this question of 
students, interviewed at different times, had no significant distinctions.

The results of other researches have shown the change in the traditional views on the sphere of upbringing of children as purely women's duty $[3,12,13]$. Thus, it has been established that in the North-West of Russia there are several ideals of paternity: a traditional model of the supporter, a model of the fissile paternity and a marginal model of paternity [13]. According to the results of our research the second of the described models is admitted by the student's circle as the most acceptable.

In turn, researchers from Great Britain have found out that an inclusion of young and highly educated fathers in the upbringing process of children and household chores promotes the growth of a birth rate in the European countries with a very low birth rate [12]. The data provided by the researchers allow drawing a conclusion that the distribution of equal gender relations in the family promotes the growth of a birth rate.

Young men and girls don't deny a possibility of upbringing of adopted children in their own family: about $35 \%$ of the respondents find it possible in the family which they will start, and about $50 \%$ find it possible only under certain conditions.

\section{Conclusion}

Thus, the results of the research allow drawing the conclusion that for the last 6 years there have been changes in family values and attitudes of students to becoming parents. These changes have concerned the significance of the family and children as terminal values, the determination of the optimum age for marriage and the orientation to the parental family as a role model during the creation of their own family. Invariable for the studied period were the ideas of the optimum number of children and the term of their birth, the distribution of gender roles in the family, the attitude to a civil marriage.

These research data have shown that the family and children are among significant values of the Russian youth. But for the last 6 years their significance has gradually decreased giving way to the career and education. Marriage in young people's view is becoming more and more free from obligations (what the approval of a civil marriage testifies to), but it assumes production in the form of the birth and upbringing of children. Only about $10 \%$ of students don't want to have children, explaining it by personal features and an insufficient level of the material welfare.

In the students' environment there are still aims oriented to creating their own family with 2 children in the future. The planned age of marriage and the birth of a child assumes waiting for the completion of the education and the creation of the career (20-30 years). The differences of opinions on these questions of the students studying in different years are that in 2019 the students called an earlier age of 20-25 as the optimum one.

For the last 6 years the share of students who in the creation of own family are inclined to consider their parents' family as an example for imitating has considerably decreased. However, even in 2019 they constituted more than a half of the total number of the respondents.

Modern students want to live separately from parents, to build the relationship with the spouse as equals and to share obligations for the upbringing of children between both parents.

The obtained data supplement already available researches of youth's family values and attitudes in Russia. The results of the research are of interest to teachers and psychologists. They can be used for the organization of the programs directed to the formation of family values and attitudes of students or to the formation of readiness of students for family life.

The work is supported by the Russian Foundation for Humanities, project № 18-013-00910

\section{References}

1. G. Bonoli, Journal of European Social Policy, 18, 1 (2008)

2. A. A. Sarcar, China Report, 51(4) (2015)

3. S. M. Bianchi, The ANNALS of the American Academy of Political and Social Science, 638, 1 (2011)

4. R.V. Rostov, Messenger of VyatGU, 4 (2012)

5. A.A. Rean, Russian Education \& Society, 60, 1 (2018)

6. Y.R. Vishnevsky, M.V. Yachmeneva, The Education and science journal, 20, 5 (2018)

7. Y. Hu, J. Scott, Journal of Family, 39 (2014)

8. D. Breton, D. Popova, F. Prioux, Revue d'Etudes Comparatives Est-Ouest, 40, 3-4 (2009)

9. A. Kuperberg, Marriage \& Family Review, 1-29 (2018).

10. L. Wright, Demography, 56 (2018)

11. S. L. Brown, W. D. Manning, K. K. Payne, Journal of Family, 38, 12 (2017)

12. O. Sullivan, F. C. Billari, E. Altintas, Journal of Family Issues, 35, 8 (2014)

13. P. Åbberg, J. Ekman, J. Rodin, International Political Science Review, 39 (2018)

14. S. Luehrmann, Journal of Women in Culture and Society, 44, 3 (2019)

15. K. A. Updegraff, J. A. Umaña-Taylor, H. K. Zeiders, D. Y. Bravo, L. B. Jahromi, Development and Psychopathology, 30 (2018)

16. P. H. P. Hanel, U. Wolfradt, G. Lins de Holanda Coelho, L. J. Wolf, R. Vilar, R. P. Monteiro, Valdiney V. Gouveia, T. Crompton, G. R. Maio, Journal of Cross-Cultural Psychology, 49, 5 (2018)

17. A. Blum, P. Sebille, S. Zakharov, Revue d'Etudes Comparatives Est-Ouest, 40, 3-4 (2009)

18. V.E. Semyonov, Sociological researches, 4 (2007) 
19. R.V. Sergeyev, Bulletin of the Adygei state university, 3 (2010)

20. N. V. Sivrikova, D. Yu. Berezhnaya, Siberian Journal of Psychology, 60 (2016)
21. A.A. Rean, Russian psychological Journal. 14, 1 (2017)

22. M. G. Keijer, A. C. Liefbroer, I. Nagel, Journal of Family, 39, 15 (2018) 